Prawne i ekonomiczne aspekty imigracji do Polski, red. Magdalena Butrymowicz, Piotr Kroczek, Kraków 2017, s. 93-124 (Biblioteczka Prawa, 2).

DOI: http://dx.doi.org/10.15633/9788374386340.07

\title{
Prawne i faktyczne mechanizmy rozlokowania uchodźców na obszarze państwa przyjmującego - doświadczenie włoskie
}

Trwający już kilka lat masowy napływ imigrantów, którzy przez Morze Śródziemne docierają do wybrzeży Włoch z zamiarem kontynuowania swej wędrówki w głąb kontynentu, stawia państwo włoskie przed koniecznością zarządzania tą napływającą w sposób ciągły falą imigracyjną. Niezbędnym jest rozlokowanie na obszarze jego terytorium setek tysięcy imigrantów ${ }^{1}$ (oficjalne dane mówią o ponad

1 Autorka artykułu świadomie unika posługiwania się pojęciem „uchodźca”, który w języku prawniczym posiada ściśle określony zakres pojęciowy związany ze spełnieniem konkretnych przesłanek prawnych (zapisanych zarówno w aktach prawa międzynarodowego, jak i aktach normatywnych poszczególnych państw). Spełnienie ich przez daną osobę przesądza bowiem o nadaniu jej szczególnego statusu „uchodźcy”, a w konsekwencji o przyznaniu jej uprawnienia do rozmaitych form ochrony międzynarodowej. I tak np. według Konwencji dotyczącej statusu uchodźców, sporządzonej w Genewie dnia 28 lipca 1951 r. (Dz.U. z 1991 r. 
180 tys. „uciekinierów” 2 , którzy przedostali się do Włoch w okresie od stycznia do grudnia 2016 roku), w stosunku do których, zgodnie $\mathrm{z}$ przepisami prawa międzynarodowego, prowadzone jest postępowanie mające ustalić ich status ${ }^{3}$.

Wszelkie kwestie związane z imigracją należą we Włoszech do kompetencji władzy centralnej, w tym wypadku działającej poprzez prefektów. To właśnie oni zobowiązani są zapewnić miejsce pobytu osobom uprawnionym do ochrony międzynarodowej. Wykorzystują do tego struktury publiczne pozostające w gestii państwa (jak np. byłe koszary, budynki należące do kolei państwowych itp.) oraz ogłaszają

Nr 119, poz. 515; tzw. konwencja genewska) uchodźca to osoba, „która żywi uzasadnioną obawę prześladowania z powodu rasy, religii, narodowości, przynależności do określonej grupy społecznej, lub poglądów politycznych, znajduje się poza terytorium kraju pochodzenia oraz nie jest w stanie lub nie chce skorzystać z ochrony tego kraju, lub nie chce do tego kraju powrócić, żywiąc obawę przed prześladowaniem”. Ta definicja „uchodźcy” była następnie uzupełniana/ modyfikowana, lecz wiąże się ona zawsze z pewnym stanem realnego zagrożenia dla życia/zdrowia osoby „uciekającej” („uchodzącej”) z miejsca swego zamieszkania. Por. Ochrona uchodźców: przewodnik po międzynarodowym prawie azylowym, http://www.unhcr-centraleurope.org/_assets/files/content/resources/ pdf_pl/legal_documents/ochrona-uchod\%C5\%BAc\% $33 \%$ B3w.-przewodnik-po-mi\%C4\%99dzynarodowym-prawie-azylowym.pdf (1.12.2016). W odmiennym wypadku mamy natomiast do czynienia z szeroko pojmowaną emigracją/imigracją (najczęściej wywołaną przyczynami ekonomicznymi), a ponieważ z oficjalnych statystyk wynika, że jedynie ok. 5 proc. przybywających do Włoch imigrantów (wnioskujących o ochronę międzynarodową) spełnia przesłanki pozwalające na przyznanie im statusu „uchodźcy”, aby uniknąć „propagandowych przekłamań”bardziej właściwym jest posługiwanie się terminem „imigranci”; stąd też, w trosce o ścisłość i poprawność języka prawniczego, wspomniany wybór autorki.

2 Włoski termin profugo oznacza właśnie „uciekiniera” (w znaczeniu potocznym również „uchodźcę").

3 Oficjalne dane statystyczne dotyczące zjawiska imigracji znajdują się m.in. na stronach włoskiego Ministerstwa Spraw Wewnętrznych i zostały przytoczone w dołączonym do artykułu aneksie: http://www.libertaciviliimmigrazione.dlci. interno.gov.it/sites/default/files/allegati/cruscotto_statistico_giornaliero_31_dicembre_o.pdf (10.01.2017). 
przetargi, w których biorą udział podmioty prywatne (struktury hotelowe, ośrodki wypoczynkowe czy też właściciele prywatnych domów), chcące (odpłatnie) gościć imigrantów. Dla społeczności lokalnej, na której terenie znajdują się tego typu struktury, oznacza to jednak szereg poważnych problemów związanych m.in. z bezpieczeństwem, dlatego też samorządy coraz częściej protestują przeciwko przysyłaniu im „uchodźców”. Prefekci zaczynają więc mieć coraz większe trudności w znalezieniu miejsca, w którym można by ich ulokować - w niektórych gminach dochodzi nawet do blokowania dróg dojazdowych przez mieszkańców.

Liczba imigrantów nielegalnie przekraczających granice Włoch wciąż wzrasta, dlatego też prefekci zmuszeni są szukać nowych rozwiązań, które pozwoliłyby im na zrealizowanie spoczywającego na nich "obowiązku rozlokowania uchodźców”. W ramach konieczności i swoistego "zarządzania kryzysowego" pojawia się niekiedy tendencja do „odkurzenia” regulacji prawnych pozwalających na zarekwirowanie własności prywatnej obywateli w sytuacji pilnej potrzeby publicznej. Stawiane są propozycje rekwirowania nie tylko struktur hotelowych czy ośrodków wypoczynkowych, schronisk, świetlic, infrastruktur sportowych itp., ale również prywatnych, niezamieszkałych domów.

Kilka ostatnich lat, a zwłaszcza dwa ostatnie (2014-2016), to okres niezwykle intensywnego napływu do Włoch przedostających się tam nielegalnie drogą morską cudzoziemców, potocznie określanych przez media mianem uchodźców. Oficjalne statystyki podają następujące liczby: 170 tys. osób w 2014 roku, 153 tys. w roku 2015 oraz około 180 tys. od stycznia do grudnia roku 2016; wskazuje się też na swoiste „rekordy” przypływów, przykładowo: w ciągu czterech dni, w drugiej połowie sierpnia, do Włoch przypłynęło ponad 13 tys. nielegalnych imigrantów, a w ciągu jednego z wrześniowych weekendów tylko do jednego z sycylijskich portów (w Mesynie) przypłynęło ich ponad 4 tys. (Mesyna liczy około 230 tys. mieszkańców). 
Od wielu już lat, praktycznie od czasu tzw. arabskiej wiosny, w następstwie której po obaleniu rządzących w Afryce Północnej reżimów nastąpił okres chaosu związany ze zmniejszeniem (czy wręcz brakiem) kontroli ze strony lokalnych władz nad niektórymi z terytoriów jej północnego wybrzeża, obserwowane jest zjawisko tzw. pokojowej inwazji uchodźców nielegalnie przedostających się do Europy. Prowadzone obserwacje i analizy tego zjawiska pokazują, że przybrało ono charakter faktycznego exodusu i że z incydentalnego przeobraziło się w zjawisko permanentne, strukturalnie wpisane w rzeczywistość współczesnych społeczeństw europejskich.

Przerzut nielegalnych imigrantów organizowany jest często przez organizacje przestępcze. $Z$ rozmaitych badań wynika, że dotyczy to około 80 proc. osób przedostających się do Europy drogą morską część z imigrantów zajmuje się później działalnością przestępczą ${ }^{4}$.

\section{Włoskie struktury organizacyjne i ich rola w zakresie udzielania pomocy imigrantom}

Obowiązek udzielania ochrony migrującym cudzoziemcom wynikający z międzynarodowych traktatów, umów i konwencji regulowany jest również przez prawo wewnętrzne poszczególnych państw. I tak na przykład konstytucja włoska, w części ogólnej poświęconej podstawowym zasadom ustroju, zawiera w art. 10 następujący zapis:

Cudzoziemiec, któremu uniemożliwiono w jego własnym kraju skuteczne korzystanie z wolności demokratycznych gwarantowanych

4 Wiele informacji związanych z tym problemem znaleźć można na przykład w: T. Reitano, L. Adal, M. Shaw, Smuggled Futures: The Dangerous Path of the Migrant from Africa to Europe, Geneva 2014, http://globalinitiative.net/wp-content/ uploads/2014/05/2014-crime.pdf (1.12.2016). 
przez konstytucję włoską, ma prawo do azylu na terytorium Republiki, według zasad ustalonych przez ustawę̧.

Sytuację cudzoziemców reguluje wiele aktów prawnych o rozmaitej randze czy zasięgu, w tym na przykład Rozporządzenie Prezydenta Republiki Włoskiej zawierające kompleksową regulację problematyki cudzoziemców oraz imigracji ${ }^{6}$ czy też Rozporządzenie Prezydenta Republiki Włoskiej’, w którym dokonuje się recepcji dyrektywy Rady 2003/9/we z dnia 27 stycznia 2003 r. Dyrektywa ta ustanawia minimalne normy oraz warunki dotyczące przyjmowania osób ubiegających się o azyl oraz definiuje pojęcie „uchodźcy”, „osoby ubiegającej się o azyl”, „osoby małoletniej pozbawionej opieki” czy też „członka rodziny osoby ubiegającej się o azyl”, natomiast wspomniane rozporządzenie reguluje m.in. zasady przyjmowania cudzoziemców wnioskujących o przyznanie im statusu uchodźcy na terenie państwa włoskiego oraz przysługujące im uprawnienia, materialne warunki ich przyjmowania oraz kompetencje odpowiednich organów w tym zakresie; zawiera ono także dyspozycje o charakterze finansowym dotyczące związanych z tym wydatków ${ }^{8}$.

5 M. Benvenuti, Il diritto di asilo nellordinamento costituzionale italiano, Padova 2007, s. 32-33; A. Cassese, Artt. 10-12 della Costituzione, w: Commentario della costituzione, red. G. Branca, Bologna-Roma 1975, s. 490-492.

6 Por. Decreto Legislativo del 25 luglio 1998, n. 286, „Testo unico delle disposizioni concernenti la disciplina dell'immigrazione e norme sulla condizione dello straniero", Gazzetta Ufficiale (dalej: GU) 18.08.1998, n. 286.

7 Por. Decreto Legislativo del 30 maggio 2005, n. 140, „Attuazione della direttiva 2003/9/CE che stabilisce norme minime relative all'accoglienza dei richiedenti asilo negli Stati membri”, GU 21.07.2005, n. 168.

8 Zob. La protezione internazionale degli stranieri in Italia. Uno studio integrato sullapplicazione dei decreti di recepimento delle direttive europee sull'accoglienza, sulle qualifiche e sulle procedure, red. M. Benvenuti, Napoli 2011, s. 32-34. 
Na szczeblu centralnym problematyka imigracji pozostaje we Włoszech w gestii ministra spraw wewnętrznych, a w szczególności Departamentu Wolności Obywatelskich i Imigracji (Dipartimento per le liberta' civili e immigrazione), który współpracuje z ministrem przy opracowywaniu polityki migracyjnej rządu oraz zajmuje się zapewnieniem przyjmowania i udzielania pomocy osobom starającym się o azyl, a także organizowaniem pierwszej pomocy dla przypływających lub też w inny sposób dostających się na terytorium Włoch nielegalnych imigrantów ${ }^{9}$.

W skład departamentu wchodzi m.in. Centralna Dyrekcja Polityki Imigracyjnej i Azylowej (Direzione centrale per le politiche dell'immigrazione e dellasilo) oraz Centralna Dyrekcja Służb Cywilnych w zakresie Imigracji i Azylu (Direzione centrale dei servizi civili per l'immigrazione e l'asilo) ${ }^{10}$, która zarządza siecią jednostek organizacyjnych takich jak ośrodki dla uchodźców (Centri di accoglienza), ośrodki identyfikacyjne czy ośrodki, w których przebywają cudzoziemcy, w stosunku do których podjęto decyzję o wydaleniu (Centri di identificazione ed espulsione). Wspomniana dyrekcja zajmuje się też ustalaniem ewentualnych kompetencji państwa włoskiego do rozpatrywania podań o udzielenie azylu, wnoszonych w ramach tzw. systemu dublińskiego, a także kontrolowaniem i monitorowaniem tzw. Systemu ochrony dla uchodźców i osób występujących o azyl (Sistema di protezione per richiedenti asilo e rifugiati, dalej: SPRAR ${ }^{11}$.

9 Zob. na stronie Dipartimento per le libertà civili e l'immigrazione, http://www. libertaciviliimmigrazione.dlci.interno.gov.it/sites/default/files/allegati/funzioni_dipartimento_dpr_210_del_2009.pdf (27.11.2016).

Pełne informacje dotyczące struktury, zadań i kompetencji wspomnianego organu znajdują się na jego oficjalnej stronie: http://www.libertaciviliimmigrazione. dlci.interno.gov.it/it/dipartimento (1.12.2016).

11 Legge del 30 luglio 2002, n. 189, „Modifica alla normativa in materia di immigrazione e di asilo", GU 26.08.2002, n. 199. 
Organy centralnej administracji rządowej wspierane są w zarządzaniu imigracją przez organy terytorialnej administracji rządowej, takie jak m.in. komendy policji, które odpowiedzialne są za wydawanie dokumentów pobytowych. Do nich właśnie składane są wnioski o ochronę międzynarodową, wnioski o wydanie zezwolenia na pobyt ze względów humanitarnych, z powodu starania się o azyl polityczny, $\mathrm{w}$ ramach ochrony uzupełniającej, w ramach integracji dla nieletnich czy w razie posiadania statusu bezpaństwowca.

Kolejnym organem jest, działająca przy prefekturach, Terytorialna Rada ds. Imigracji, której zadaniem jest monitorowanie obecności imigrantów w poszczególnych prowincjach oraz wspomaganie współpracy pomiędzy podmiotami instytucjonalnymi, które $\mathrm{w}$ ramach swych zadań zajmują się imigracją.

Kompetencje w zakresie imigracji mają też komisje terytorialne do spraw przyznania statusu uchodźcy, które rozpatrują wnioski o przyznanie statusu uchodźcy i decydują o jego przyznaniu bądź odmo$w_{i e}{ }^{12}$. W razie odmowy komisja może jednak zwrócić się o wydanie zezwolenia na pobyt ze względów humanitarnych ${ }^{13}$.

Zarządzanie napływem tak wielkiej liczby cudzoziemców na terytorium Włoch stwarza konieczność zapewnienia ścisłego współdziałania organów, organizacji i instytucji zarówno rządowych, jak i samorządowych różnego szczebla.

Realizując koncepcję zarządzania wielopoziomowego, Włochy stworzyły system SPRAR, obejmujący sieć rozmaitych instytucji, jednostek organizacyjnych i tym podobnych podmiotów lokalnych, które

Funkcjonują one w następujących miastach: Gorizia, Milano, Torino, Roma, Caserta, Foggia, Bari, Crotone, Trapani e Siracusa.

13 Decreto Legislativo del 28 gennaio 2008, n. 25, „Attuazione della direttiva 2005/85/CE recante norme minime per le procedure applicate negli Stati membri ai fini del riconoscimento e della revoca dello status di rifugiato", GU 16.02.2008, n. 40 . 
mają za zadanie udzielanie tzw. zintegrowanej gościny uchodźcom ${ }^{14}$. Gościnność zintegrowana polega nie tyko na zapewnieniu mieszkania i wyżywienia osobom podlegającym ochronie międzynarodowej i występującym o azyl, ale też na towarzyszeniu im w procesie poznawania terytorium, tak aby umożliwić im efektywne korzystanie z rozmaitych instrumentów, które mają do dyspozycji, w tym z dostępu do socjalnych zasobów lokalnych, takich jak na przykład opieka szkolna czy społeczno-sanitarna ${ }^{15}$. Obejmuje ona też działania mające pomóc takim osobom uzyskać znajomość języka włoskiego, a niejednokrotnie też wyprowadzić je z analfabetyzmu, oraz działania mające umożliwić małoletnim realizację obowiązku szkolnego.

Dołączają się do tego również konkretne inicjatywy o charakterze informacyjno-prawnym, których celem jest udzielanie zainteresowanym osobom informacji o procedurach umożliwiających przyznanie im ochrony międzynarodowej czy też o prawach i obowiązkach związanych z przyznanym im statusem uchodźcy ${ }^{16}$.

Realizowane w ramach systemu SPRAR projekty terytorialne, których celem jest towarzyszenie każdej z goszczonych osób na jej drodze do zyskania/odzyskania autonomii, łączą zintegrowaną gościnę z usługami nakierowanymi na społeczno-ekonomiczną integrację

14 Pełen opis wspomnianego systemu SPRAR oraz jego funkcji i zadań znajduje się na jego stronie: http://www.sprar.it/attivita-e-servizi (1.12.2016); zob. też Manuale operativo 2015, http://www.sprar.eu/images/sPRAR_-_Manuale_operativo_2015. $\operatorname{pdf}(1.12 .2016)$.

$15 \mathrm{~W}$ temacie integracji imigrantów zob. m.in. M. De Marco, Ufficio Immigrazione Caritas Italiana. Dossier Statistico Immigrazione Caritas/Migrantes, w: L'evoluzione storica della normativa sull'immigrazione, red. F. Pittau, Roma 2013, s. $10-12$.

16 Por. Richiesta di asilo e rifugiati, http://www.dirittierisposte.it/Schede/Persone/ Immigrazione-e-cittadinanza/richiesta_di_asilo_e_rifugiati_id1120473_art.aspx (1.12.2016). 
uchodźcó $\mathrm{w}^{17}$. W ramach wspomnianych projektów organizowane są często rozmaite kursy czy szkolenia mające na celu formację bądź przekwalifikowanie zawodowe, tak aby umożliwić imigrantom wejście na rynek $\operatorname{pracy}^{18}$, a także podejmowane są działania mające pomóc im w uzyskaniu własnego mieszkania. Działalność podejmowana w ramach powyższego systemu SPRAR finansowana jest $\mathrm{z}$ Krajowego Funduszu na rzecz Polityki Azylowej ${ }^{19}$.

SPRAR charakteryzuje się ponadto: dobrowolnością przystąpienia i udziału w nim lokalnych podmiotów i jednostek organizacyjnych; decentralizacją zadań realizowanych w ramach zintegrowanej gościny; współdziałaniem z tzw. jednostkami zarządzającymi, czyli podmiotami z trzeciego sektora, na których spoczywa główny ciężar realizacji postawionych w projekcie celów, oraz promocją i rozwojem lokalnych sieci złożonych z różnorakich instytucji i podmiotów, których współpraca i zaangażowanie przesądza o powodzeniu działań na rzecz integracji osób objętych międzynarodową ochroną ${ }^{20}$.

W terytorialnych projektach realizowanych $\mathrm{w}$ ramach SPRAR uczestniczą aktywnie zarówno duże miasta, jak i małe centra - metropolie i prowincjonalne miasteczka. W odróżnieniu od systemu występującego w większości państw europejskich Włochy zdecydowały się na wdrażanie projektów integracyjnych o małych i średnich rozmiarach, opracowywanych i wprowadzanych w życie na poziomie lokalnym, przy bezpośrednim udziale funkcjonujących tam podmiotów, uznając,

17 Zob. Cittadini possibili. Un nuovo approccio all'accoglienza e all'integrazione dei rifugiati, red. M. Ambrosini, C. Marchetti, Milano 2008, s. 36-38.

18 Zob. M. Catarci, L'integrazione dei rifugiati. Formazione e inclusione nelle rappresentazioni degli operatori sociali, Milano 2011, s. 23-25.

19 Por. Progetti territoriali, http://www.sprar.it/progetti-territoriali?sort_order=i$\mathrm{d}+\mathrm{asc}(1.12 .2016)$.

20 Por. Piano di ripartizione e Clausola di salvaguardia, http://www.sprar.it/piano-di-ripartizione-e-clausola-di-salvaguardia (1.12.2016). 
iż przyczyni się to do wzmocnienia otwartości na obecność imigrantów wśród ludności oraz poprzez integrację społeczno-ekonomiczną ułatwi ich przenikanie do lokalnej tkanki społecznej ${ }^{21}$.

\section{Mechanizmy rozlokowywania imigrantów na obszarze Włoch}

Po przedostaniu się na terytorium Włoch i po złożeniu wniosku o uznanie statusu uchodźcy i o udzielenie azylu osoba ubiegająca się o ochronę międzynarodową ma prawo do korzystania z pomocy finansowej państwa aż do czasu, w którym decyzja o przyznaniu bądź odmowie przyznania ochrony międzynarodowej stanie się ostateczna ${ }^{22}$.

Pomoc ta obejmuje zapewnienie jej mieszkania i wyżywienia, a także tzw. kieszonkowego na pokrycie kosztów łączności z pozostawionymi w kraju pochodzenia bliskimi. Po uzyskaniu zezwolenia na pobyt czasowy, w okresie trwania procedury azylowej (średnio ponad 6 miesięcy), osobom tym przysługuje prawo do opieki społecznej i zdrowotnej; nieletni mają zapewniony dostęp do szkół publicznych, dorośli do bezpłatnych kursów i szkoleńn ${ }^{23}$. Jeżeli procedury azylowe przeciągają się na okres powyżej 6 miesięcy, wnoszący o azyl mają również prawo do podjęcia pracy. Mogą też wystąpić o przyznanie im zapomogi pieniężnej ${ }^{24}$.

21 Zob. S. Sarti, L'Italia dei rifugiati, Roma 2010.

22 Por. La tutela del richiedente asilo. Manuale giuridico per l'operatore (2012), http:// www.sprar.it/guide-normative/guide-pratiche-per-operatori (27.10.2017).

23 Decreto del Ministero dell'Interno, 1 settembre 2016, „Istituzione di centri governativi di prima accoglienza dedicati ai minori stranieri non accompagnati”, GU 8.09.2016, n. 210.

24 Dokładne informacje dotyczące mechanizmów prawnych, procedur i aspektów praktycznych udzielania gościny przybywającym do Włoch imigrantom znajdują 
Zgodnie z prawem włoskim państwo ma obowiązek udzielenia gościny wszystkim, którzy zwracają się o przyznanie im azylu, a ponieważ ich już i tak wielka liczba wciąż rośnie, koniecznym staje się ich redystrybucja na całym terytorium Włoch ${ }^{25}$. Dokonuje się tego w różny sposób - najprostszy polega na tym, że władze centralne wykorzystują rozmaite struktury będące własnością państwa, jak np. nieużywane koszary, budynki administracji publicznej, struktury sportowe itp., które po odpowiednim przystosowaniu służą jako miejsca tymczasowego pobytu imigrantów ${ }^{26}$.

Problem rozlokowania imigrantów wiąże się ściśle z relacjami na płaszczyźnie: władze centralne (działające poprzez rozmaite organy rządowej administracji terytorialnej) - władze samorządowe, czyli tzw. autonomia lokalna. Te pierwsze bowiem, zgodnie z przyznanymi im przez prawo kompetencjami, mają za zadanie zarządzanie kwestiami związanymi z udzielaniem ochrony cudzoziemcom, w razie potrzeby narzucając swą wolę władzom lokalnym, które z kolei, wyrażając

się m.in. w sporządzonym przez ekspertów rządowych i firmowanym przez Ministerstwo do Spraw Wewnętrznych raporcie: Rapporto sull'accoglienza di migranti e rifugiati in Italia. Aspetti, procedure, problemi Gruppo di studio sul sistema di accoglienza, Roma 2015, http://www.asylumineurope.org/sites/default/ files/resources/ministry_of_interior_report_on_reception_of_migrants_and_refugees_in_italy_october_2015.pdf (1.12.2016). Zob. także Storia del diritto d'asilo in Italia dal dopoguerra ad oggi. Quadro normativo, http://www.altrodiritto.unifi. it/ricerche/asilo/suprano/cap3.htm (1.12.2016).

25 Prawa osób ubiegających się o ochronę międzynarodową na obszarze Włoch oraz związane z tym obowiązki instytucji publicznych: zob. Richiesta di asilo..., dz. cyt.

26 Na temat zajmowania struktur publicznych i prywatnych na potrzeby imigrantów por. m.in. Pazza idea del governo: scuole e seconde case per ospitare migranti, http://www.secoloditalia.it/2016/o4/pazza-idea-del-governo-scuole-e-seconde-case-per-ospitare-migranti (1.12.2016); Hotel, palasport, caserme Dove finiscono i profughi, http://www.ilgiornale.it/news/politica/hotel-palasport-caserme-dove-finiscono-i-profughi-1160415.html (1.12.2016). 
wolę mieszkańców, coraz częściej sprzeciwiają się narzuconej przez władze centralne liczbie przydzielanych im uchodźców ${ }^{27}$.

Dystrybucją imigrantów w ramach poszczególnych terytoriów i znalezieniem dla nich odpowiednich struktur, które udzieliłyby im gościny, zajmują się prefekci, reprezentujący rząd na płaszczyźnie lokalnej ${ }^{28}$. Stoją oni na czele wspomnianych już terytorialnych rad do spraw imigracji (Consigli Territoriali per l'Immigrazione), które monitorują obecność imigrantów na obszarze danego terytorium oraz określają jego możliwości odnośnie przyjmowania ich dalszego napływu $^{29}$. Prefekci organizują m.in. centra dla uchodźców, których prowadzenie powierzają $\mathrm{w}$ ramach podpisywanych umów i konwencji rozmaitym podmiotom użyteczności publicznej ${ }^{30}$.

Ogłaszane są też przetargi publiczne i konkursy na zorganizowanie struktur przyjmujących uchodźców, w których biorą udział rozmaite organizacje użyteczności publicznej non-profit, organizacje

27 Por. Il Veneto si sente assediato Profughi violenti e proteste, http://www.ilgiornale. it/news/politica/veneto-si-sente-assediato-profughi-violenti-e-proteste-1325794. html (27.11.2016). Stąd też coraz częściej dąży się do zawierania oficjalnych porozumień pomiędzy prefektem a władzą lokalną, które zawierałyby reguły przyjmowania imigrantów na obszarze ich działania. Przykład takiego porozumienia: Protocollo d'intesa tra: Prefetture delle Marche, Regione Marche, Associazione Nazionale Comuni Italiani (ANCI MARCHE), http://www.ancimarche.it/wp-content/ uploads/2016/o6/Protocollo_intesa.pdf (16.12.2016).

28 Por. Competenze di Prefettura e Questura, http://www.nuovicittadini-prefto.it/ materiali/immigrazione/83-competenze-di-prefettura-e-questura (1.12.2016).

29 Por. Decreto del Presidente del Consiglio dei Ministri, 18 dicembre 1999, GU Serie Generale 18.01.2000, n. 13) oraz Consigli territoriali per l'immigrazione, http://www.libertaciviliimmigrazione.dlci.interno.gov.it/it/consigli-territoriali-limmigrazione (1.12.2016).

30 Por. Rapporto sulla protezione internazionale in Italia 2016, http://www.sprar.it/ wp-content/uploads/2016/12/Rapporto-protezione-internazionale-in-Italia-2016SINTESI.pdf (7.12.2016). 
humanitarne czy inne organizacje pozarządowe ${ }^{31}$. Podmioty, które wygrywają taki przetarg czy konkurs, otrzymują od państwa środki pieniężne przeznaczone na utrzymanie uchodźców (około 35 euro dziennie na osobę) i w ten sposób bezpośrednio, z pominięciem władz samorządowych, porozumiewają się z właścicielami nieruchomości położonymi na terenie danej gminy (np. właścicielami hoteli, domów wypoczynkowych, ale także struktur religijnych czy prywatnych mieszkań), którzy za opłatą (a w niektórych wypadkach nawet „gratis") oddają swe lokale do dyspozycji uchodźców ${ }^{32}$. Praktyka pokazuje jednak, że rodzi to bardzo liczne nadużycia, gdyż z jednej strony, mimo systemu kontroli, dochodzi do korupcji już na etapie organizowania przetargu, a z drugiej - podmiot zarządzający środkami państwowymi przeznaczonymi na utrzymanie imigrantów niejednokrotnie defrauduje jakąś część tej kwoty33.

31 Decreto del Ministero dell'Interno, 5 agosto 2010, „Linee guida per la presentazione delle domande di contributo per il Fondo nazionale per le politiche e i servizi dell'asilo", GU 30.09.10, n. 229.

Por. Fini sbugiardato: ecco tutti gli hotel che ospitano profughi, http://www.ilgiornale.it/news/politica/fini-sbugiardato-ecco-tutti-hotel-che-ospitano-profughi-1200062.html (7.12.2016).

33 Dlatego też - zwłaszcza w ostatnim roku - coraz częściej opisywane jest zjawisko tzw. imigracyjnego biznesu; zamieszane są w to nawet międzynarodowe organizacje pozarządowe mające wśród swoich statutowych celów m.in. „wspieranie uchodźców”, które - jak się okazuje - współdziałają z przemytnikami imigrantów, pomagając im w organizowaniu nielegalnych "transportów uchodźców” do Włoch. W ostatnich miesiącach sprawą tą zajęła się oficjalnie włoska prokuratura. Por. Ong che aiutano gli scafisti. Ora indagano due procure, http://www.ilgiornale. it/news/politica/ong-che-aiutano-scafisti-ora-indagano-due-procure-1367716. html (7.12.2016). Specyficzny „biznes” związany z „uchodźcami” obejmuje też najprzeróżniejsze podmioty prywatne, poczynając od instytucji zajmujących się organizowaniem pobytu imigrantów we Włoszech, aż po indywidualnych właścicieli mieszkań, którzy wynajmują je na potrzeby imigrantów. Koszty ich działań pokrywane są ze środków publicznych. Przykładowo na utrzymanie 900 imigrantów w Trieście organizacje („społeczno-humanitarne”) otrzymały ostatnio $12 \mathrm{mln}$ euro, a w Mantova 4,3 mln euro na utrzymanie 450 imigrantów. Por. Trieste, 
Taki sposób rozlokowywania uchodźców na obszarze poszczególnych terytoriów w ostatnich miesiącach okazuje się jednak coraz trudniejszy, a niekiedy wręcz niemożliwy z powodu coraz liczniejszego dopływu imigrantów, coraz bardziej kurczących się zasobów lokalowych łatwo dostępnych oraz coraz mniejszej dyspozycyjności społeczności lokalnych odmawiających przyjmowania cudzoziemców, którzy stwarzają liczne problemy, również w dziedzinie porządku publicznego ${ }^{34}$. Bardzo często są to bowiem osoby nieposiadające żadnych dokumentów czy też posiadające fałszywe/skradzione dokumenty tożsamości - osoby, które po przybyciu do Włoch „znikają”, pozostając poza wszelką kontrolą ${ }^{35}$.

12 milioni alla coop per accogliere gli immigrati, http://www.newslocker.com/it-it/ notizie/generale/trieste-12-milioni-alla-coop-per-accogliere-gli-immigrati/view (7.12.2016); A Roma torna il business dell'accoglienza, http://www.ilgiornale.it/ news/politica/roma-torna-bussiness-dellaccoglienza-1200927.html (26.10.2017); Mantova, soldi per i profughi: 4,3 milioni di euro alle coop, è polemica, http:// www.sestopotere.com/mantova-soldi-per-i-profughi-43-milioni-di-euro-alle-coop (1.12.2016).

34 Spośród niezwykle obszernej dokumentacji związanej z tym problemem wspomnieć można o następujących przypadkach: Profughi: il prefetto chiama, i Comuni frenano, http://gazzettadimantova.gelocal.it/mantova/cronaca/2015/o7/25/ news/i-sindaci-dei-centri-piu-piccoli-non-abbiamo-strutture-per-i-migranti-e-la-lega-attacca-li-ospitino-a-palazzo-di-bagno-1.11834092 (17.11.2016); Profughi, sindaci e residenti in rivolta contro il piano del prefetto di Roma, http://www. ilgiornale.it/news/politica/profughi-sindaci-e-residenti-rivolta-contro-piano-prefetto-r-1132476.html (17.11.2016). Niemniej liczna jest dokumentacja dotycząca protestów mieszkańców, nierzadko zresztą zabranianych przez władze: Arrivano troppi clandestini? È vietato protestare, http://www.ilgiornale.it/news/ politica/arrivano-troppi-clandestini-vietato-protestare-1164719.html (17.11.2016). Według oficjalnych danych w ciągu ostatnich 2 lat „zniknęło”, wymykając się spod kontroli instytucji publicznych, około 100 tys. nielegalnych przybyszów, z których większość nadal przebywa na terytorium Włoch. Por. In due anni spariti 10omila migranti Sono in Italia, ma ora da clandestini, http://www.ilgiornale.it/news/politica/due-anni-spariti-10omila-migranti-sono-italia-ora-133450o. html (17.12.2016). Dochodzi do tego również problem tzw. unaccompanied minor, czyli małoletnich, którzy przybyli na teren Włoch bez opieki rodziców. Ze 
Dlatego też niekiedy dochodzi nawet do tymczasowego rekwirowania (odpłatnego) prywatnych nieruchomości, a zwłaszcza struktur hotelowych, na potrzeby imigrantów ${ }^{36}$. Pojawiają się też propozycje wprowadzenia rozwiązań prawnych umożliwiających wykorzystanie w tym celu nieruchomości podlegających zajęciu komorniczemu w okresie poprzedzającym ich sprzedaż, co budzi bardzo duże kontrowersje z powodu nieuchronnej utraty ich wartości (przebywający w nich uchodźcy teoretycznie mieliby się troszczyć o utrzymanie ich w stanie, w jakim zostały im powierzone) ${ }^{37}$. Swoistą „ciekawostką" jest fakt, iż poszukując podstaw prawnych umożliwiających działania tego typu (jak na przykład w wypadku zarekwirowania hotelu w Castel d'Azzano w prowincji Verona) odwołano się m.in. do historycznej ustawy z 1865 roku, której jeden z zapisów pozwalał władzom

statystyk wynika, że ok. 54 proc. deklaruje wiek 17 lat, a kolejnych 27 proc. 16 lat. Zważywszy na bardzo niedokładne metody ustalenia wieku (opierające się na badaniu rozwoju kości i dające wynik z oficjalnym marginesem błędu 2-3 lat), z dużym prawdopodobieństwem można przypuszczać, że są to osoby pełnoletnie, chcące wykorzystać uprzywilejowany status prawny związany z niepełnoletniością. Por. Protocollo per l'identificazione e per l'accertamento olistico multidisciplinare delletà dei minori non accompagnati, https://www.minori.gov.it/ sites/default/files/protocollo_identificazione_msna.pdf; Via libera dal Senato alla norma che tutela $i$ minori stranieri non accompagnati, https://www.democratica. com/focus/via-libera-dal-senato-alla-norma-che-tutela-i-minori-stranieri-non-accompagnati/?cn-reloaded $=1$ (1.03.2017).

36 Por. «Tensioni sulla gestione dei profughi, l'accoglienza diffusa è l'unica strada». Incontro dei sindaci in Provincia. Bergamin: le soluzioni vanno trovate, http://corrieredelveneto.corriere.it/veneziamestre/notizie/politica/2016/18-novembre-2016/ tensioni-gestione-profughi-l-accoglienza-diffusa-l-unica-strada-2401068504705. shtml (1.12.2016).

37 Spore kontrowersje i protesty wzbudziła np. propozycja Dario Colassanti, sędziego z Lecco, aby umieszczać uchodźców w prywatnych domach czy mieszkaniach, które podlegają zajęciu komorniczemu w związku z długami ich właścicieli. Por. Tribunale di Lecco: usare le case pignorate per ospitare gli immigrati, http:// www.imolaoggi.it/2016/10/29/tribunale-di-lecco-usare-le-case-pignorate-per-ospitare-gli-immigrati (1.12.2016). 
publicznym na „dysponowanie własnością prywatną w razie bardzo poważnej potrzeby publicznej" ${ }^{38}$.

Wobec wielkiej niepopularności tego typu rozwiązań naruszających własność prywatną prefekci chętnie korzystają z oferowanych przez system SPRAR możliwości lokowania imigrantów przy wykorzystaniu sieci publicznych i prywatnych struktur, którymi system ten zarządza ${ }^{39}$.

Prowadzone przez rozmaite ośrodki obserwacje i analizy zjawiska napływu uchodźców pozwalają stwierdzić, iż obecnie nie może ono już być traktowane jako coś nadzwyczajnego, przejściowego, a więc możliwego do opanowania przy wykorzystaniu instrumentów zarządzania kryzysowego. Przeobraziło się ono bowiem w zjawisko strukturalne, trwale wpisane w rzeczywistość współczesnej Europy i jako takie wymagające strukturalnych, a nie tylko doraźnych rozwiązań. Aktualny system udzielania gościny imigrantom zaczyna więc wchodzić w fazę krytyczną, co skłania rząd włoski do poszukiwania nowych, bardziej adekwatnych rozwiązań. Pojawiają się coraz bardziej kompleksowe propozycje, takie jak chociażby ta zgłoszona w styczniu przez Zrzeszenie Konstruktorów Budowlanych, którzy mając na uwadze potrzeby imigrantów, postulują zrewidowanie dotychczasowej polityki mieszkaniowej i podjęcie budowy (w oparciu o środki

38 Por. Albergo requisito per gli immigrati in nome dei... Savoia. Nel Veronese per dare un tetto ai profughi il governo ha riesumato una legge del 1865, http:// it.geosnews.com/p/sm/albergo-requisito-per-gli-immigrati-in-nome-dei-savoia-nel-veronese-per-dare-un-tetto-ai-profughi-il-governo-ha-riesumato-una-legge-del-1865_13251265 (17.12.2016).

Por. statystyki form działań organizowanych i realizowanych przez SPRAR, http:// www.sprar.it/i-numeri-dello-sprar (1.12.2016); zob. też Emergenza migranti: 40 cose da sapere, http://www.repubblica.it/solidarieta/immigrazione/2015/og/o1/ news/migranti_profughi_cose_da_sapere_domande_risposte_faq-121963703 (17.11.2016). 
finansowe publiczne) wielu nowych miast/dzielnic przeznaczonych docelowo dla masowo napływających przybyszów ${ }^{40}$.

Zauważyć można, iż do tej pory znaczna większość z przyjmowanych na terenach poszczególnych gmin imigrantów rozlokowywana była w ramach tzw. nadzwyczajnego obiegu, czyli na podstawie bezpośredniego zarządzenia prefekta, w wielu wypadkach bez wcześniejszego uzgodnienia z władzami samorządowymi, co często prowadziło do nadmiernej koncentracji uchodźców i zachwiania proporcji pomiędzy przybyszami a mieszkającymi na danym terenie obywatelami włoskimi ${ }^{41}$.

Powodowało to i nadal powoduje silne napięcia i konflikty na obszarach rozmaitych gmin, związane również z umieszczaniem na ich terytorium osób, które nie uzyskały jeszcze wystarczającej autonomii koniecznej dla samodzielnego funkcjonowania, co nieuchronnie prowadzi do ich degradacji i do związanego z tym wzrostu ryzyka dla bezpieczeństwa publicznego, powodując dodatkowe obciążenie dla instytucji publicznych ${ }^{42}$.

40 Por. Migranti, Assoedilizia: servono nuovi alloggi, rivedere le politiche urbanistiche, http://www.imolaoggi.it/2016/10/20/migranti-assoedilizia-servono-nuovi-alloggi-rivedere-le-politiche-urbanistiche (1.12.2016); zob. też P. Briata, Spazio urbano e immigrazione in Italia. Esperienze di pianificazione in una prospettiva europea, Milano 2014.

41 Por. Nel borgo di 197 abitanti ospitati 900 profughi, http://www.csvteramo.it/ images/Giornaleo20916_Borgo.pdf (1.12.2016).

42 Spośród bardzo licznej dokumentacji tego problemu wskazać tu można następujące przypadki: Nardella vuole sanzionare i Comuni che rifiutano i migranti, https:// infosannio.wordpress.com/2016/10/27/nardella-vuole-sanzionare-i-comuni-che-rifiutano-i-migranti (22.11.2017); Toscana, 54 Comuni a zero profughi. Rossi: penalità a chi non ospita, http://corrierefiorentino.corriere.it/firenze/notizie/ cronaca/16_ottobre_27/toscana-54-comuni-zero-profughi-rossi-penalita-chi-non-ospita-1f73d8o6-9c14-11e6-ada6-dc55oce1883e.shtml (22.11.2017); Liguria, Puglia, la rossa Toscana È tutto il Paese che dice basta, http://www.ilgiornale.it/ 
Alternatywą według Ministerstwa Spraw Wewnętrznych może być więc wspomniany już SPRAR, który z jednej strony gwarantuje władzom samorządowym dobrowolne przystępowanie do proponowanych projektów czy inicjatyw, a z drugiej zapewnia ich realizowanie przy udziale wykwalifikowanego personelu, zgodnie z zasadami transparentności działań administracji publicznej, umożliwiając też monitorowanie prowadzonych w jego ramach działań. System ten w 95 proc. finansowany jest ze środków ogólnopaństwowych ${ }^{43}$.

Wydane w listopadzie tego roku przez ministra spraw wewnętrznych zarządzenie zawiera też swoistą klauzulę, tzw. klauzulę ochronną, przewidującą zwolnienie gmin, które dobrowolnie do wspomnianego systemu przystąpiły lub zgłosiły do niego swój akces, z obowiązku przyjmowania uchodźców z tzw. bezpośredniego przydziału prefekta. Klauzula ta ma umożliwić władzom samorządowym, aby wraz z lokalną społecznością ustaliły sposoby przyjmowania imigrantów, ich liczbę (nie może ona jednak być mniejsza niż ta, która została odgórnie przydzielona im przez prefektów), a także wskazały podmioty, które będą zaangażowane w dany projekt. W celu ułatwienia gminom przystępowania do wspomnianego systemu zrezygnowano z jakichkolwiek ograniczeń czasowych, uproszczono też odpowiednie procedury ${ }^{44}$. Jego funkcjonowanie, nakierowane na jak najszerszy udział jednostek terytorialnych, miałoby doprowadzić do maksymalnej „dyfuzji” imigrantów na obszarze całych Włoch, co według ministerstwa pozwoliłoby z jednej strony na zmniejszenie napięć

news/politica/liguria-puglia-rossa-toscana-tutto-paese-che-dice-basta-1323987. html (22.11.2017).

$\mathrm{Na}$ temat systemu SPRAR i jego roli w zarządzaniu imigracją por. m.in Manuale operativo 2015, dz. cyt.

44 Por. Immigrazione - Decaro e Biffoni scrivono ai Comuni su attivazione clausola di salvaguardia per accoglienza nello Sprar, http://www.anci.it/index.cfm?layout=dettaglio\&IdDett=58082 (1.12.2016). 
powodowanych masową obecnością imigrantów na niektórych obszarach, a z drugiej na ich szybszą i pełniejszą integrację z lokalnymi społecznościami ${ }^{45}$.

\section{Praktyczne aspekty/problemy związane z goszczeniem imigrantów}

Podejmowane przez rząd reformy dotychczasowego systemu przyjmowania „uchodźców napływających na terytorium Włoch” stanowią próbę rozwiązania licznych problemów, które w związku z tym powstają ${ }^{46}$. Są wśród nich m.in. podejmowane w trybie pilnym decyzje prefektów o obowiązkowym "przydzielaniu” gminom imigrantów, które niejednokrotnie prowadzą do paradoksalnych sytuacji, kompletnie zaburzających proporcje między goszczącymi a goszczonymi ${ }^{47}$.

Stąd też coraz częściej pojawiają się blokady dróg dojazdowych lub inne akcje mające na celu uniemożliwienie przyjazdu imigrantów. Wśród nich wspomnieć można o: szczególnie nagłośnionym

45 Por. cytowany już dokument: Protocollo d'intesa...

46 Temat ten jest szeroko analizowany m.in przez P. Mori, Profili problematici dell'accoglienza dei richiedenti protezione internazionale in Italia, Diritto dell'Unione Europea (II), fasc. 1, 2014; zob. też A. Villa, Immigrazione: legislazione italiana tra fonti del diritto e rappresentazione sociale, Messina 2008.

47 I tak np. w malutkiej osadzie Musi di Lusevera w prowincji Udine, w której mieszka sześć rodzin, umieszczonych zostało, w lokalu zarządzanym przez jedną z organizacji non-profit, ośmiu imigrantów; w miejscowości, Vignetto di Cassano (Piacenza), gdzie mieszka dziewięciu obywateli włoskich, ulokowano piętnastu uchodźców z Bangladeszu i umieszczono w domu wynajętym w tym celu przez prywatną osobę; w miejscowościach Cona i Bagnoli w prowincji Wenecja na 9 tys. mieszkańców przypada 1250 imigrantów; trzyipółtysięczne Salorno w prowincji Bolzano gości prawie tysiąc uchodźców; w liczącej 100 mieszkańców miejscowości Pietrafazzana w prowincji Chieti chciano ulokować 50 imigrantów, po protestach od zamiaru chwilowo odstąpiono, lecz następnie wrócono do poprzedniej idei i ulokowano tam około 100 imigrantów. 
(i silnie piętnowanym) przez prasę przypadku małej, liczącej ok. 4 tys. mieszkańców, miejscowości Gorino w prowincji Ferrara, której mieszkańcy postawili barykady na drogach dojazdowych, uniemożliwiając umieszczenie tam imigrantów ${ }^{48}$; miasteczku Capalbio - tzw. perełce turystyki (prowincja Grosetto, Toskania) - które zaprotestowało przeciw przyjęciu 50 imigrantów - sam burmistrz zwrócił się do wojewódzkiego sądu administracyjnego z wnioskiem o zmniejszenie ich liczby ${ }^{49}$; rzymskich dzielnicach, takich jak np. Aurelia czy Magliana, gdzie zdesperowani narastającym chaosem mieszkańcy wychodzą na ulicę, aby zaprotestować przeciw kolejnym ośrodkom dla uchodźców oraz wznoszą barykady ${ }^{50}$; czy też dzielnicach w pobliżu stacji kolejowej Tiburtina, gdzie według oficjalnych danych organizacji humanitarnych w ciągu ubiegłego roku przebywało około

48 Por. Gorino, barricate contro 12 migranti: «Dicono 11 donne, poi diventa un'invasione», http://www.corriere.it/cronache/16_ottobre_26/dicono-undici-donne2d911842-9afo-11e6-97ec-6obd8f16d4a5.shtml?refresh_ce-cp (27.11.2016).

Por. Vittoria radical chic Il prefetto ci ripensa Capalbio è offlimits per i richiedenti asilo, http://www.ilgiornale.it/news/politica/vittoria-radical-chic-prefetto-ci-ripensa-capalbio-limits-i-1335251.html (27.11.2016).

50 Jest to reakcja również na pogarszające się warunki sanitarne związane $\mathrm{z}$ nielegalnymi koczowiskami imigrantów, które ulokowane są w przestrzeni publicznej: w parkach, na parkingach, a nawet niekiedy (przy sprzyjających warunkach pogodowych) bezpośrednio na ulicach, co skutkuje także znacznym wzrostem przestępczości. Próby likwidacji tego typu koczowisk są jednak bojkotowane przez sądy administracyjne - dochodzi do uchylania zarządzenia burmistrza nakazującego likwidację nielegalnych koczowisk przez Regionalny Trybunał Administracyjny (Tribunale Amministrativo Regionale, dalej: TAR) - tak jak np. w Trieście, gdzie na wniosek obywatela Pakistanu oczekującego na decyzję w sprawie przyznania mu azylu (i wraz z wieloma innymi osobami „biwakującemu w mieście pod gołym niebem") zarządzenie takie zostało uchylone przez TAR. Zob. Migranti, il Tar annulla l'ordinanza „antibivacco” emessa dal sindaco di Trieste, http:// www.lastampa.it/2016/12/12/italia/cronache/migranti-il-tar-annulla-lordinanza-antibivacco-emessa-dal-sindaco-di-trieste-BMdNdpYcFu12pzBvp9vouk/pagina. html (10.02.2016). 
40 tys. imigrantów ${ }^{51}$. Emblematycznym przykładem jest też Mediolan, w którym burmistrz zmuszony został uznać porażkę prowadzonej polityki „otwartych drzwi”, która doprowadziła do takiego wzrostu przestępczości, że koniecznym stało się wsparcie sił porządkowych przez wprowadzenie na ulice patroli wojskowych..$^{52}$

Wobec coraz częstszych protestów mieszkańców i coraz liczniejszych obywatelskich komitetów obrony przed tzw. zalegalizowaną inwazją uchodźców - prefekci, w poszukiwaniu dostępnych miejsc dla imigrantów, uciekają się do różnych sposobów: niektórzy oferują pieniądze podmiotom prywatnym, a konkretnie rodzinom, które za goszczenie u siebie imigrantów miałyby otrzymywać 400 euro miesięcznie (tzw. działania rasistowskie w stosunku do obywateli włoskich) ${ }^{53}$, inni wykorzystują sale gimnastyczne szkół publicznych, historyczne wille i pałace, bazy wojskowe, koszary, instytuty badawcze czy też inne tego typu struktury będące własnością publiczną ${ }^{54}$.

Kolejnym sposobem, do którego uciekają się prefekci, jest umieszczanie imigrantów w rozmaitych „pustostanach”. Mechanizm jest następujący: państwo wynajmuje (np. od deweloperów czy też

51 Por. Maxi-centro migranti a Tiburtina: a Roma scoppia la polemica, http://gossip. libero.it/focus/35927530/maxi-centro-migranti-a-tiburtina-a-roma-scoppia-la-polemica/roma-maxi-centro/?type= (27.11.2016).

52 Por. „A Milano più militari e meno profughi”. Alfano ammette il fallimento, http:// www.ilgiornale.it/news/milano/pi-militari-e-meno-profughi-alfano-ammette-fallimento-1333762.html (1.12.2016). Przy tej okazji komentatorzy zaobserwowali swoisty paradoks polegający na tym, iż Włochy są chyba jedynym państwem na świecie, które ogłasza mobilizację wojska, aby broniło obywateli przed tymi, których włoska Marynarka Wojenna dopiero co uratowała i przewiozła do Włoch, praktycznie od samych wybrzeży Afryki (!).

53 Por. A chi ospita profughi 400 euro. «Razzismo contro gli italiani», http://www.selpress.com/unionecommercio/immagini/050116M/2016010528779.pdf (1.12.2016).

54 Por. Emergenza migranti, Milano: 400 euro al mese per chi decide di ospitarli in casa, http://www.huffingtonpost.it/2016/o1/o4/40o-euro-migranti-milano_n_8911022. html (27.11.2016). 
w strukturach hotelarskich zorganizowanych na zasadzie kontraktów „timesharingu”) niesprzedane lokale i przeznacza je na ośrodki dla uchodźców - powoduje to bardzo negatywne konsekwencje dla właścicieli, gdyż znacznie obniża się wartość ich nieruchomości ${ }^{55}$. Zdarza się w związku z tym, że mieszkańcy, zwłaszcza w małych miejscowościach, organizują zbiórkę pieniędzy i przekazują ją właścicielowi hotelu, po to aby zrezygnował z oddawania go do dyspozycji imigrantów ${ }^{56}$.

Dyspozycyjność miejsc, w których można by ulokować imigrantów, coraz bardziej maleje, gdyż często po kilkumiesięcznym okresie wynajmu lokale oddawane są właścicielom w bardzo złym stanie. Niekiedy też imigranci, którym zostały one przydzielone, podnajmują je swoim nielegalnie przebywającym na terenie Włoch „współziomkom”, co sprawia, że zamiast przewidzianych np. pięciu osób lokal zamieszkiwany jest przez trzy razy większą ich liczbę.

55 Por. Profughi nelle case nuove, la furia dei vicini, http://www.ilgiorno.it/monza-brianza/cronaca/profughi-convivenza-rischio-1.2352895 (1.12.2016).

56 Tak jak np. w liczącej 600 osób miejscowości Monterosso Grana w prowincji Cuneo, gdzie prefekt zaplanował wynajęcie dla uchodźców struktury hotelowej mogącej pomieścić około 200 osób. Właściciel wspomnianej struktury zdecydował się na jej wynajęcie, żeby w ten sposób, uzyskując środki finansowe, zapobiec jej likwidacji. W tej sytuacji mieszkańcy podjęli decyzję o „samoopodatkowaniu” i przeznaczeniu pochodzących stąd środków (a także specjalnie wyasygnowanej na ten cel kwoty ze środków gminnych) jako wsparcie finansowe dla właściciela hotelu, aby ten odstąpił od zamiaru wynajęcia go na potrzeby imigrantów. Zob. „Paghiamo noi l'albergatore per rifiutare gli immigrati”, http://www.ilgiornale.it/news/politica/paghiamo-noi-lalbergatore-rifiutare-immigrati-1318469. html (1.12.2016). Z podobnym sposobem działania spotkać się można również w Szwajcarii, gdzie np. mieszkańcy małej, zamożnej miejscowości Oberwil-Lieli zdecydowali w drodze referendum, że aby uniknąć goszczenia na swym terenie „przydziałowych imigrantów” - zapłacą władzy centralnej nadzwyczajny podatek (w wysokości ponad 260 tys. euro), tak aby ta znalazła dla nich „alternatywną lokalizację". Por. Svizzera, paese anti-immigrati dice si a super tassa per non accogliere i profughi, http://www.ilfattoquotidiano.it/2016/05/o1/svizzera-paese-anti-immigrati-dice-si-a-super-tassa-per-non-accogliere-i-profughi/2687533 (27.11.2016). 
Właściciele hoteli i domów wczasowych, w których umieszczani są imigranci, ponoszą też konsekwencje w postaci spadku liczby turystów, którzy wycofują się z wynajmowanych imigrantom obiektów i to bynajmniej nie ze względów rasistowskich (ma to ścisły związek ze sposobem zachowania się imigrantów, przyzwyczajonych do innych standardów kultury, którzy np. wyrzucają śmieci bezpośrednio przez okna, na wspólnych korytarzach urządzają swoiste „salony fryzjerskie” czy też kuchnie albo miejsca spotkań, nie zachowują podstawowych zasad higieny itp. $)^{57}$.

Mieszkający wspólnie z imigrantami Włosi, zwłaszcza osoby starsze, niejednokrotnie skarżą się na agresywne zachowania przybyszów, co powoduje znaczne obniżenie ich poczucia bezpieczeństwa ${ }^{58}$.

Jak duży jest już problem z brakiem miejsc, pokazują oficjalne wypowiedzi prefektów, którzy grożą sankcjami władzom samorządowym odmawiającym przyjmowania uchodźców, sugerując, iż burmistrzowie ci wywierają nielegalne naciski na właścicieli struktur prywatnych wyrażających chęć goszczenia imigrantów, którzy przystępują do przetargów publicznych na zorganizowanie ośrodka dla imigrantów, a następnie się wycofują. I tak na przykład prefekt Wenecji w oficjalnym wywiadzie stwierdził, że będzie denuncjował burmistrzów z tytułu „przestępstwa utrudniania przez nich przetargów publicznych"59.

57 Por. „Le nostre case? Occupate dai migranti”, http://www.ilgiornale.it/news/politica/doveva-essere-soluzione-provvisoria-diventata-definitiva-1177748.html (27.11.2016).

58 Por. Vivere con gli immigrati fa male alla salute, lo dice perfino il medico, http:// www.ilgiornale.it/news/politica/vivere-immigrati-fa-male-salute-dice-perfino-medico-1311829.html (27.11.2016).

59 Por. La minaccia del prefetto: „Davanti al giudice chi non accoglie profughi”, http://247.libero.it/rfocus/25432617/1/la-minaccia-del-prefetto-davanti-al-giudice-chi-non-accoglie-profughi (1.12.2016). 
Kolejne sankcje, którymi grożą władzom lokalnym prefekci, to sankcje typu ekonomicznego, jak na przykład odebranie ulg podatkowych czy dotacji wypłacanych przez państwo tym gminom, które odmawiałyby przyjmowania uchodźców ${ }^{60}$.

Obawy mieszkańców wiążą się z bardzo konkretnymi aspektami goszczenia imigrantów. Brak kontroli nad przybyszami (również sanitarnej) powoduje, że osoby takie realnie zagrażają ich bezpieczeństwu (gwałty i molestowanie), niejednokrotnie wchodzą oni we współpracę z organizacjami przestępczymi i zasilają ich szeregi, zwłaszcza w charakterze handlarzy narkotyków. Wzrasta też zagrożenie dla bezpieczeństwa publicznego - zwiększa się liczba rekrutujących do „walki z niewiernymi”, jest więc swoistą „ciekawostką”, iż włoski sąd kasacyjny wydał niedawno orzeczenie, iż samo wzywanie do zorganizowania dżihadu, „świętej wojny” w imię Allacha, nie może być traktowane jako przestępstwo ${ }^{61}$. Oburzają też opinię publiczną nasilające się protesty i niepokoje wzbudzane przez imigrantów, którzy niekiedy w sposób bardzo gwałtowny dochodzą swoich racji ${ }^{62}$.

6o Szokująca opinię publiczna propozycja została złożona np. przez prefekta Verbanii (Piemont), który zachęcił obywateli, aby przekazali oni na potrzeby imigrantów swoje domy letniskowe. Por. II prefetto di Verbania: „Agli immigrati le vostre case". Idea choc per aiutare i profughi, http://247.libero.it/focus/35915843/48/ ii-prefetto-di-verbania-agli-immigrati-le-vostre-case-idea-choc-per-aiutare-i-profughi (1.12.2016).

61 Por. Incitazione al martirio non è terrorismo, dice la Cassazione, http://www. ilfoglio.it/cronache/2016/11/14/news/incitazione-al-martirio-non-e-terrorismo-dice-la-cassazione-106652 (1.12.2016); Inneggia a jihad e a Bin Laden. Ma il giudice lo fa scarcerare, http://www.ilgiornale.it/news/cronache/inneggia-jihad-e-bin-laden-giudice-fa-scarcerare-1333984.html (1.12.2016).

62 Imigranci protestują m.in. przeciwko: identyfikacji za pomocą pobrania linii papilarnych; jedzeniu, które im nie odpowiada; zbyt małej (według nich) ilości pieniędzy; za długim kolejkom podczas wydawania posiłków; braku bezprzewodowego Internetu; niewystarczającej liczby doładowań kart telefonicznych; bonom towarowym (w zamian chcą pieniędzy); symbolom chrześcijańskim 
Coraz częściej sygnalizowane są też nadużycia związane z wykorzystywaniem środków publicznych przeznaczonych na opłacanie pobytu imigrantów ${ }^{63}$, przekazywanych rozmaitym podmiotom niejednokrotnie bez respektowania zasad obowiązujących w takich przypadkach, w tym transparentności, monitorowania wydatków czy kontroli zrealizowanych przy tej okazji efektów.

\section{Podsumowanie}

Sytuacja, która wytwarza się w związku z koniecznością rozlokowania na terenie państwa przyjmującego cudzoziemców ubiegających się o udzielenie im ochrony międzynarodowej, podlega stałej i szybkiej

w miejscach publicznych, takich jak np. cmentarz. Por. „Vogliamo le ricariche” I profughi in strada bloccano il centro città, http://www.ilgiornale.it/news/politica/vogliamo-ricariche-i-profughi-strada-bloccano-centro-citt-1241515.html (27.11.2016); Cagliari, protesta migranti 'No impronte', http://www.ansa.it/sardegna/notizie/2016/03/25/cagliariprotesta-migranti-no-impronte_b3487560-4ccd42d1-8de3-ecofb76f 4667.html (1.12.2016); „Al cimitero troppi simboli cristiani”, http://www.ilgiornale.it/news/politica/cimitero-troppi-simboli-cristiani-1287728. html (1.12.2016); Palermo, rivolta nel centro migranti sovraffollato, http://palermo. repubblica.it/cronaca/2016/03/28/news/palermo_rivolta_nel_centro_migranti_sovraffollato-136428833 (1.12.2016); Milano, protesta dei nigeriani al centro d’accoglienza: „La pasta non ci piace”, http://www.imolaoggi.it/2017/o1/18/milano-protesta-dei-nigeriani-al-centro-daccoglienza-la-pasta-non-ci-piace (1.12.2016); Ecco il menù a 5 stelle che gli immigrati rifiutano, http://www.ilgiornale.it/news/ cronache/ecco-men-5-stelle-che-immigrati-rifiutano-1240111.html (1.12.2016); „Dateci cibo e pocket money!”. Esplode la protesta dei clandestini, http://www. ilpopulista.it/news/4-Ottobre-2016/5540/dateci-cibo-e-pocket-money-esplode-la-protesta-dei-clandestini.html (1.12.2016).

63 Zjawisko to było wielokrotnie opisywane przez włoskie media. Spośród licznych przykładów wspomnianych nadużyć wskazać tu można na opisane w poniższym artykule przypadki oszustw związanych z zarządzaniem funduszami przeznaczonymi na potrzeby imigrantów. Zob. Le Coop dello scandalo che lucrano milioni sulla finta solidarietà, http://www.ilgiornale.it/news/politica/coop-dello-scandalo-che-lucrano-milioni-sulla-finta-1348617.html (1.03.2017). 
ewolucji - jaki będzie jej rozwój, zależeć będzie od wielu bardzo zróżnicowanych czynników, w tym o charakterze ściśle politycznym. Analiza opisanych tu zjawisk pozwala na zindywidualizowanie rozmaitych mechanizmów nimi sterujących - zarówno legalnych, działających w sposób jawny, jak i tych niezgodnych z prawem; i choć często ukrytych pod hasłami solidaryzmu czy humanitaryzmu - w rzeczywistości będących jedynie „przykrywką” dla realizacji olbrzymich interesów ekonomicznych, a często i politycznych.

Z punktu widzenia praktyczno-prawnego problemy z rozlokowywaniem imigrantów pokazują konieczność wypracowania skutecznych form współdziałania pomiędzy centralnymi a lokalnymi instytucjami politycznymi, które przybrały we Włoszech postać zorganizowanego systemu SPRAR. W ramach wspomnianego systemu próbuje się wdrażać na poziomie lokalnym projekty integracyjne, realizując je przy bezpośrednim udziale funkcjonujących tam podmiotów, tak aby doprowadzić do wzrostu otwartości na obecność imigrantów wśród ludności oraz poprzez integrację społeczno-ekonomiczną ułatwić ich przenikanie do lokalnej tkanki społecznej. Doświadczenia włoskie, ze względu na uniwersalność problemów związanych z masowym napływem imigrantów, mogą być więc szczególnie cenne dla krajów niemających jeszcze własnych doświadczeń w tej dziedzinie. 
Rysunek 1. Dane dotyczące liczby imigrantów, którzy w okresie od 1 stycznia do 31 grudnia 2016 roku przedostali się na terytorium Włoch drogą morską, w zestawieniu z takim samym okresem z lat 2014 (wzrost o 6,66 proc.) i 2015 (wzrost o 17,94 proc.).

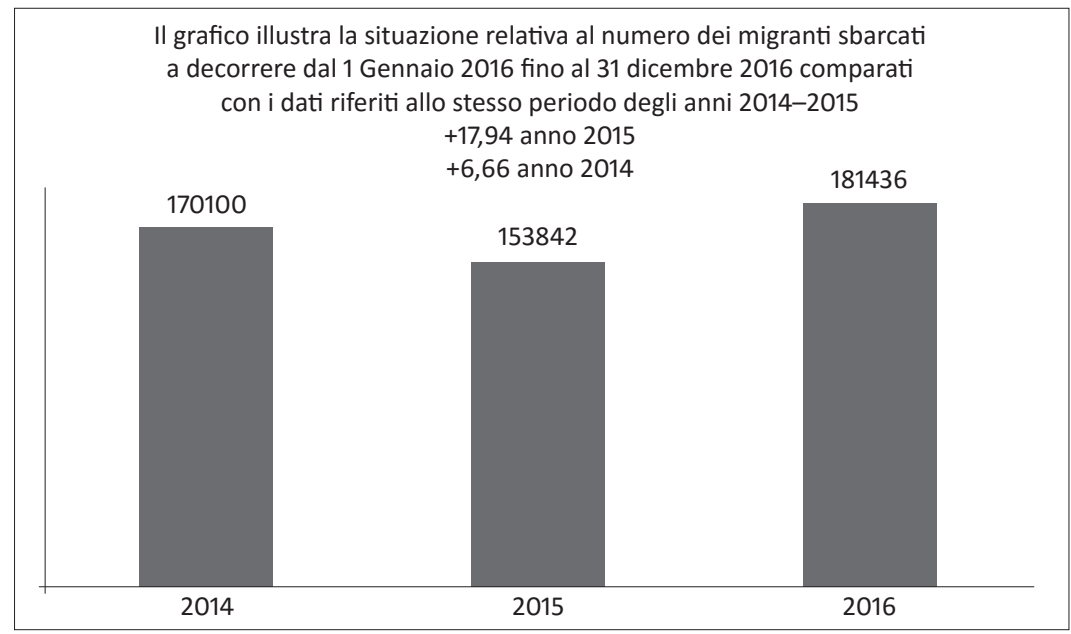

Źródło: dane Departamentu Wolności Obywatelskich i Imigracji (Dipartimento per le liberta' civili e immigrazione) Ministerstwa Spraw Wewnętrznych

Rysunek 2. Dane dotyczące liczby małoletnich imigrantów, którzy w okresie od 1 stycznia do 31 grudnia 2016 roku przedostali się na terytorium Włoch drogą morską, bez opieki rodziców, w zestawieniu z takim samym okresem z lat 2014 i 2015.

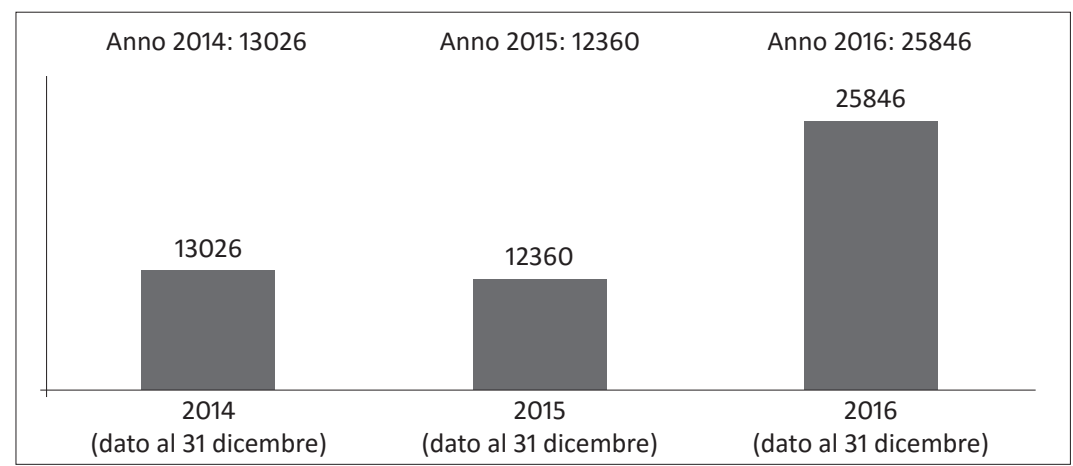

Źródło: dane Departamentu Wolności Obywatelskich i Imigracji Ministerstwa Spraw Wewnętrznych 
Tabela 1. Dane liczbowe dotyczące narodowości zadeklarowanej przez imigrantów, którzy w 2016 roku przedostali się na terytorium Włoch drogą morską.

\begin{tabular}{|c|c|}
\hline \multicolumn{2}{|c|}{ Nazionalità dichiarate al momento dello sbarco anno 2016 (aggiomato al 31/12/2016) } \\
\hline Nigeria & 37551 \\
\hline Eritrea & 20718 \\
\hline Guinea & 13342 \\
\hline Costa d'Avorio & 12396 \\
\hline Gambia & 11929 \\
\hline Senegal & 10327 \\
\hline Mali & 10010 \\
\hline Sudan & 9327 \\
\hline Bangladesh & 8131 \\
\hline Somalia & 7281 \\
\hline altre & 40424 \\
\hline Totale & 181436 \\
\hline
\end{tabular}

Źródło: dane Departamentu Wolności Obywatelskich i Imigracji Ministerstwa Spraw Wewnętrznych

Tabela 2. Dane procentowe dotyczące narodowości zadeklarowanej przez imigrantów, którzy w 2016 roku przedostali się na terytorium Włoch drogą morską.

\begin{tabular}{|c|c|}
\hline \multicolumn{2}{|c|}{ Nazionalità dichiarate al momento dello sbarco al 31/12/2016 } \\
\hline Nigeria & $21 \%$ \\
\hline Eritrea & $11 \%$ \\
\hline Guinea & $7 \%$ \\
\hline Costa d'Avorio & $7 \%$ \\
\hline Gambia & $7 \%$ \\
\hline Senegal & $6 \%$ \\
\hline Mali & $6 \%$ \\
\hline Sudan & $5 \%$ \\
\hline Bangladesh & $4 \%$ \\
\hline Somalia & $4 \%$ \\
\hline altre & $22 \%$ \\
\hline Totale & $100 \%$ \\
\hline
\end{tabular}

Źródło: dane Departamentu Wolności Obywatelskich i Imigracji Ministerstwa Spraw Wewnętrznych 
Rysunek 3. Dane dotyczące rezultatów rozpatrzenia przez odpowiednie organy wniosków azylowych złożonych przez imigrantów w okresie od stycznia do października 2016 roku. 3 proc. uzyskało status uchodźcy (rifugiati); 11 proc. uzyskało ochronę zastępczą (sussidiaria); 21 proc. ochronę ze względów humanitarnych (umanitaria); 65 proc. wniosków odrzucono (diniego).

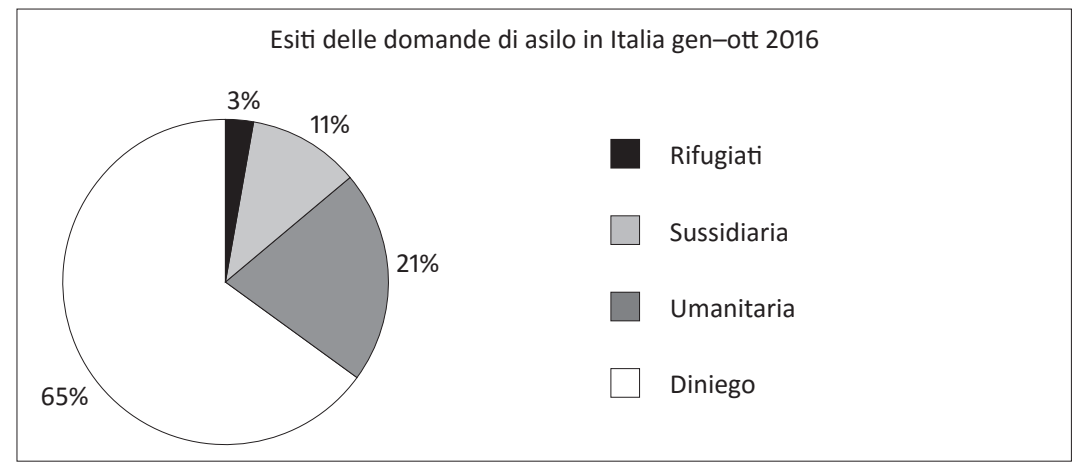

Źródło: dane Włoskiej Rady ds. Uchodźców (Consiglio Italiano per i Rifugiati)

Rysunek 4. Dane dotyczące płci (po lewej stronie rysunku) i wieku (po stronie prawej) imigrantów składających wnioski azylowe w 2015 roku (91,27 proc. mężczyźni; 8,73 proc. kobiety). 82,41 proc. wniosków złożonych zostało przez osoby w wieku od 18-34 lat (!).

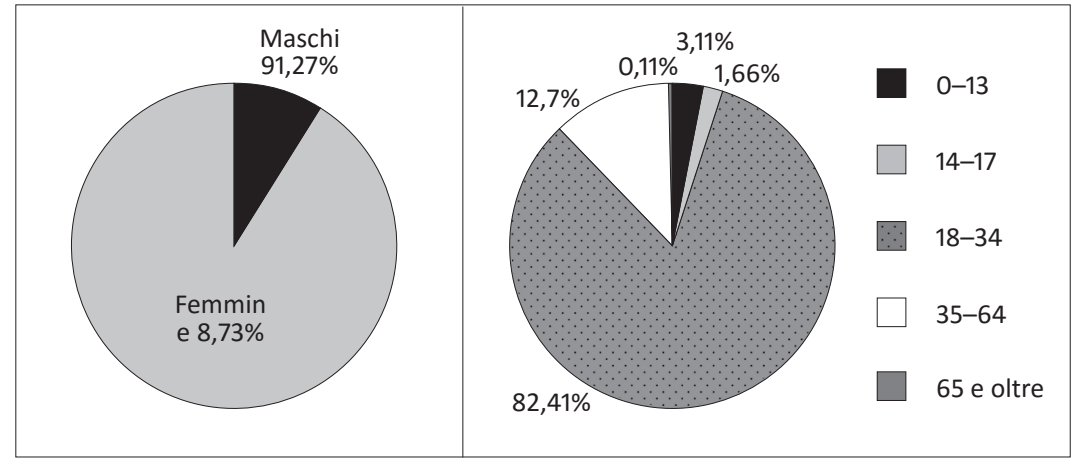

Źródło: dane Centralnego Urzędu Statystycznego Ministerstwa Spraw Wewnętrznych 
Rysunek 5. Dane dotyczące rezultatów rozpatrzenia przez odpowiednie organy wniosków azylowych złożonych przez imigrantów w okresie od stycznia do lipca 2016 roku. 5 proc. uzyskało status uchodźcy (rifugiati); 12 proc. uzyskało ochronę zastępczą (sussidiaria); 18 proc. ochronę ze względów humanitarnych (umanitaria); 65 proc. wniosków odrzucono (diniego) - w zestawieniu z całym rokiem 2015. U dołu rysunku dane dotyczące 5 narodowości, których obywatele najliczniej wystąpili o azyl w okresie od stycznia do lipca 2016 roku w zestawieniu z całym rokiem 2015.

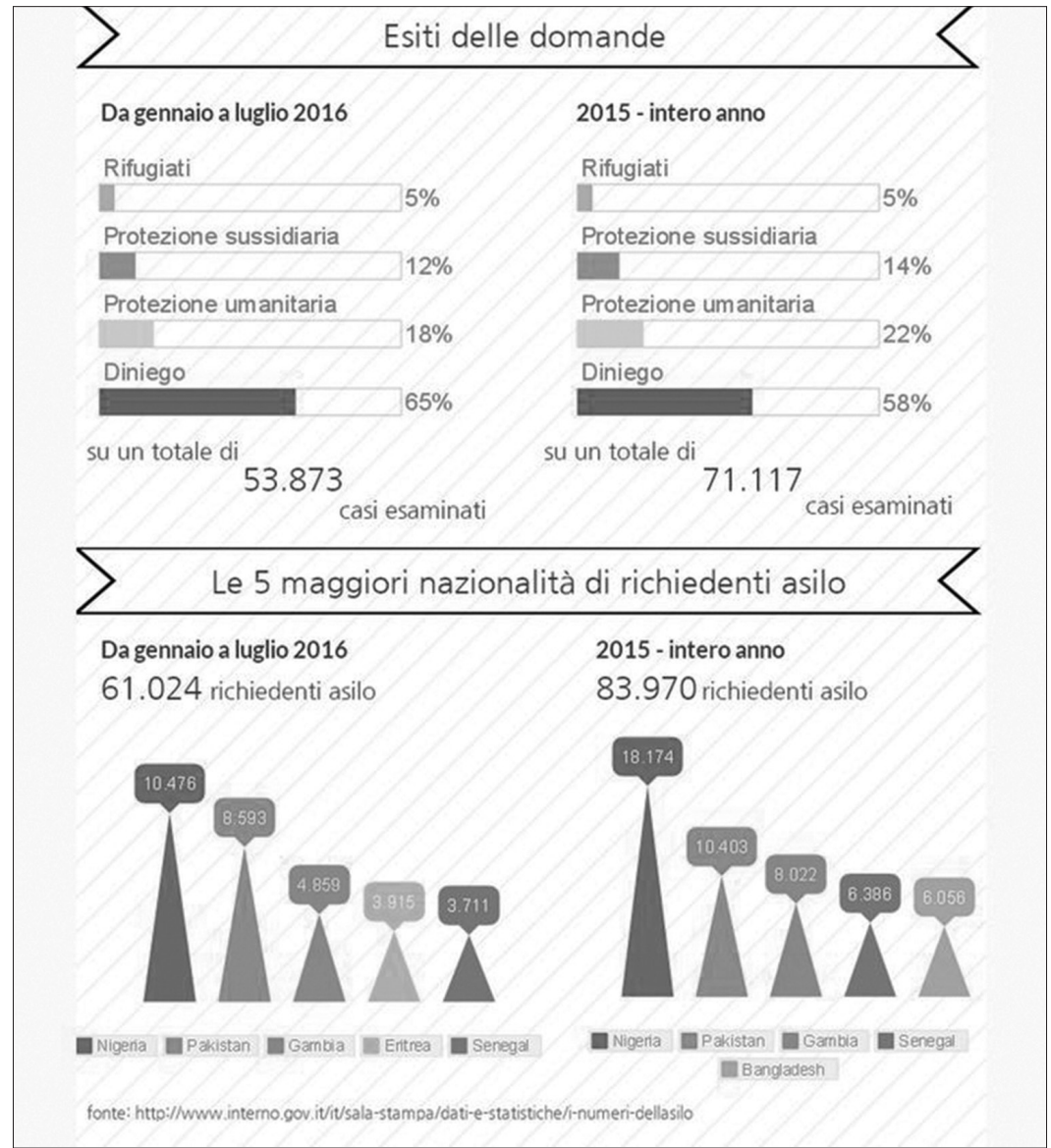

Źródło: dane Departamentu Wolności Obywatelskich i Imigracji Ministerstwa Spraw Wewnętrznych 
Tabela 3. Dane dotyczące procentowego rozlokowania na obszarze poszczególnych regionów imigrantów, którzy w okresie od 1 stycznia do 31 grudnia 2016 roku przedostali się na terytorium Włoch drogą morską.

\begin{tabular}{|c|c|}
\hline \multicolumn{2}{|c|}{ Distribuzione percentuale migranti divisa per regione presenze totali $176554(31 / 12 / 2016)$} \\
\hline Lombardia & $13 \%$ \\
\hline Lazio & $8 \%$ \\
\hline Veneto & $8 \%$ \\
\hline Piemonte & $8 \%$ \\
\hline Campania & $8 \%$ \\
\hline Sicilia & $8 \%$ \\
\hline Toscana & $7 \%$ \\
\hline Emilia-Romagna & $7 \%$ \\
\hline Puglia & $7 \%$ \\
\hline Calabria & $4 \%$ \\
\hline Liguria & $3 \%$ \\
\hline Sardegna & $3 \%$ \\
\hline Friuli-Venezia Giulia & $3 \%$ \\
\hline Marche & $3 \%$ \\
\hline Abruzzo & $2 \%$ \\
\hline Molise & $2 \%$ \\
\hline Umbria & $2 \%$ \\
\hline Basilicata & $1 \%$ \\
\hline Provincia Autonoma di Bolzano & $1 \%$ \\
\hline Provincia Autonoma di Trento & $1 \%$ \\
\hline Valle d'Aosta & $0,2 \%$ \\
\hline
\end{tabular}

Źródło: dane Departamentu Wolności Obywatelskich i Imigracji Ministerstwa Spraw Wewnętrznych

\section{Summary}

Legal and real mechanisms of resettling refugees in the area of the receiving country - the Italian experience

For several years Italy has been facing the problem of finding accommodation for the mass inflow of immigrants to its shores (according to the official data, 
180 ooo illegal immigrants entered Italy in 2016), following the requirements stated by international regulations to investigate their status. In Italy the central government, represented by Prefects, is responsible for dealing with immigration. In face of the increasing scale of the problem connected with finding suitable living quarters for immigrants, Prefects are forced to look for new solutions, which will help them fulfil the duty of refugees "resettlement”. They use public structures belonging to the state (such as former barracks or buildings belonging to state railways) and launch tenders for private bodies which want to offer shelter to immigrants in return for payment (hotels, holiday resorts or owners of private houses). Sometimes, when there are no tenders, they consider requisitioning not only hotels, holidays resorts, shelters, community centers and sports infrastructure, but also private uninhabited houses. Pursuing the concept of multi-level governance, Italy has developed The Protection System for Asylum Seekers and Refugees (SPRAR), which covers a net of various institutions, organizations and other local agencies whose aim is to offer so called integrated hospitality to refugees. Keywords: refugees, immigrants, protection system, asylum, The Protection System for Asylum Seekers and Refugees (SPRAR) 